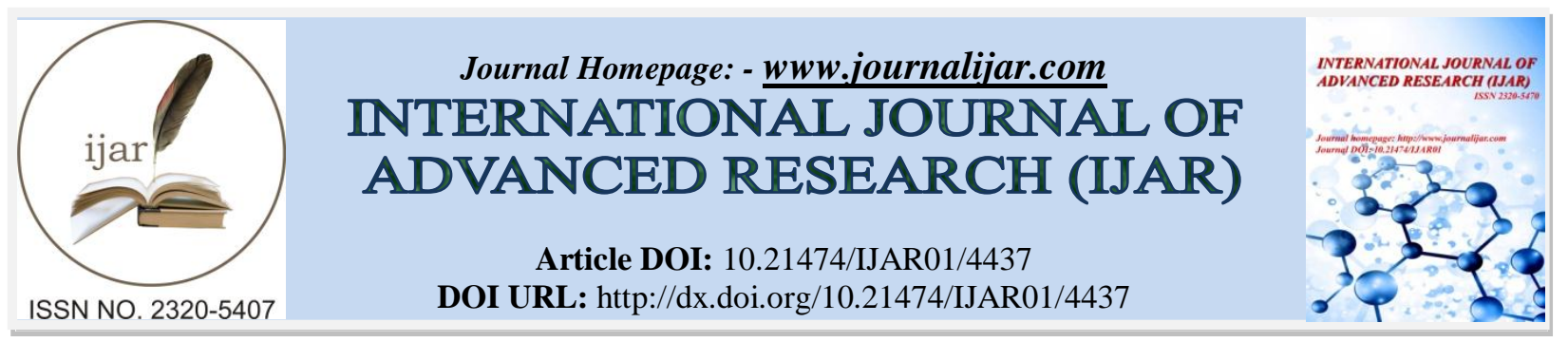

RESEARCH ARTICLE

\title{
PRIMARY EDUCATION IN INDIA: AN ELUCIDATION OF POLICY INITIATIVES, ACCOMPLISHMENT AND CONTRADICTIONS.
}

Uma Sheokand.

Research Fellow, Panjab University, Chandigarh (India)-160014.

\section{Manuscript Info}

\section{Manuscript History}

Received: 10 April 2017

Final Accepted: 12 May 2017

Published: June 2017

Key words:-

Education for All, Primary Education,

Educational Growth

\section{Abstract}

India is a signatory to the Millennium Declaration, adopted by 191 United Nations members' states in September 2000, and the plan of Action of a World Fit for Children has been central to the focus of India, which envisage achieving universal access to free and compulsory education by 2015. India has taken several initiative programmes, policies and practices to reach educational goals in the nation especially over the last decade and a half.

The central focus of the paper is to identify successful and unsuccessful country efforts to move towards achievement of the universal goals of primary education in India started under the flag of international campaign of "Education for All". There has been great progress in the last decade in primary education in India. The gender, caste and demographic disparities in primary education have markedly reduced at national, state and at grass root levels. But challenges like universal enrolment, universal retention, dropout rate and quality education are still big hurdles in achievement of universal goals of primary education in India, which demands strong political will, and administrative dedication of the educational authorities. An attempt has been made to in this paper to discuss the policy initiatives by Government of India, to throw light on the success achieved, challenges faced and remedies for the achievement of $100 \%$ enrollment and retention rate in primary education to achieve the goals of universal primary education in India.

Copy Right, IJAR, 2017,. All rights reserved.

\section{Introduction:-}

Education is a dynamic force in the life of every individual influencing the physical, mental, emotional, ethical and social development of the individual. Therefore, every child must have access to early education that is of good quality. The primary education is the foundation of learning for life, it ensures whether the child will become a good citizen or not. Children are the future of any country and primary education is the first stepping stone towards the educational literacy of a child. To make child, a better citizen, primary education plays a very significant role. It provides a sound base for learning and helps to develop skills, knowledge, development of a sense of social responsibility and all round personality development. Primary education should be a basic human right, as it is both transformative and empowering. Beyond this intrinsic importance, it is also indispensable for the enjoyment of other human rights and is a means for accessing broader social, economic, political and cultural rights and benefits. 'Primary education must be ensuring that children have positive experiences and that their needs for health, 
stimulation and support are met, and that they learn to interact with their surroundings' (UNESCO 2007) Education contributes to building more just societies through reducing poverty and inequalities. No country has ever climbed the human development ladder without steady investment in education. ${ }^{1}$

\section{Objective:-}

The objective of the subject matter is to analyze the results of international campaign of Education for All on primary education in India while stating other various other national initiatives undertaken by Government of India to improve the primary education in India.

\section{Methodology:-}

For analyzing the results of international campaign of Education for All initiative and other national initiatives for upliftment of primary education in India, secondary data have been used. As the subject matter focuses on the analysis of the condition of Primary education in India the data have been collected from United Nations Development Programme (UNDP), World Bank, Ministry of Human Resource and Development (MHRD) and National Educational University of Planning and Administration (NEUPA) website for the analysis of the condition of Primary education in India. Besides it, the analysis of newspaper reports and authentic online data will also form the part of data. This paper will also enlist the growth of Primary education in India that has undergone in last decade on the basis of available data.

\section{International Campaign of Education for All:-}

The commitment to provide primary education to every child is the oldest of the Millennium Development Goals, having been set at the first World Declaration of Education for All in Jomtien, Thailand in 1990. India was also a participative member of this international campaign of "Education for All" (EFA). To review the progress of EFA campaign, its second meeting was held in Dakar, Senegal in April 2000 and India not only participated but also reframed its national education policy as per the Dakar Declaration and the framework of Action (2001). The main actions set by this meeting are shown in figure 1

Figure 1:- Declaration of Dakar Framework for Action ${ }^{2}$

Expending and Improving Comprehensive Early Childhood

Care and Education and Ensuring Learning Needs of all young neople

Ensuring that by 2015 all children have access to and complete, free and Compulsory Primary Education of Good Quality

Eliminaing gender disparities in Primary and Secondary

Education by 2005 and Achieving Gender Equality by 2015

and Improving Ouality of Education

As expressed in the Universal Declaration of Human Rights and the UN Convention on the Rights of the Child, to receive education and primary education is the part of "Education for All" campaign. The 'Primary Education' in India refers to the basic education imparted to 6 to 14 years of children. It comprises of 5 years of school education i.e. Class I to V for 6-11 age group students. India's commitment to the goal of Education for All is exemplified by range of strategies and actions initiated since 1990 to achieve the goal of 'Education for All' in the shortest possible time period.

\footnotetext{
${ }^{1}$ Thematic Paper on MDG 2 UNDG, Available at http://www.undg.org/docs/11421/MDG2_1954UNDG-MDG2-LR.pdf. Accessed on 12th January 2014.

2 Adopted by World Education Forum, Dakar, Senegal, 26-28, April 2000 (Education For All Goals)
} 


\section{National Perspective and Education for All Campaign: A Case of India:-}

An educated and enlightened citizen is essential for the success of democracy. During the independence of India in 1947 almost 85 per cent of our population was illiterate and only about 31 per cent of children in the age group 6- 11 went to schools. Education is a powerful driver of development and one of the strongest instrument for improving health, gender equality, peace, and stability and reducing poverty, so the Constitution of India has, laid down under the Article 45 that "The state shall endeavor to provide within a period of 10 years from the commencement of this Constitution for the free and compulsory education of all children until they complete the age of fourteen."Article 46 mandated that "The State shall promote with special care the educational and economic interest of the weaker sections of the people, and in particular of the Schedule Casts and Schedule Tribes, and shall protect them from social injustice and all forms of exploitation." Education in India has been on the 'Concurrent List' since 1976. There is meaningful partnership between the Centre and States. There are constitutional provisions and mechanisms for sharing of resources, planning, division of powers and responsibilities and harmonization of their respective powers in the larger national interest and welfare. Government of India has taken strong steps with a view to realizing the Constitutional Directives of Universal Elementary Education (UEE).

Education was emphasized not only by Constitution, but also by global leaders. Successive development policies and Five Years Plans too laid emphasis on the expansion of education in the country.

\section{Key milestones in India's march towards Primary Education:-}

The Indian government took several steps including the setting up of the education Commission besides framing many programmes and policy initiatives. The Kothari Commission (1964-66) was set up to formulate a coherent education policy. This Commission comprehensively reviewed the entire educational system and Commission reported that Indian education system needed a drastic realignment and reorganization. This Commission gave many suggestions and recommendations to improve education system in India. The Government of India also expressed strong political will by implementing its recommendations in form of "The National Policy of Education (NPE) $1968 ”$

The National Policy of Education (NPE) 1968 was necessary for "radical restructuring" and equalization of educational opportunities and commitment to the universalistion of elementary education. NPE 1968 marked a significant step in the history of education in post independence India. The overall objective of the government was to make education relevant to the emerging environment by way of encouraging social and economic skills. The National Policy of Education (NPE) 1968 has expressed strong political commitment to the Universalisation of elementary education. The programme of action (POA) was started in 1985 for implementing the NPE has rightly observed, NPE give an unqualified priority to Universalisation of elementary education (UEE). The Government of India took many steps to implement NPE, which are Universal Enrolment and Universal Retention; Universalisation of facilities; Curriculum improvement; Teacher Training and Dynamic methods of teaching; Social Enlightenment and Awareness. The National Policy of Education (1986 and 1992) " policy was a key milestone in India's march towards goals of "education for all" campaign. It stated that "In our national perception, education is essentially for all. The main objective of the National Policy of Education of 1986/92 (Programme of Action, 1992) was to develop a national system of education to express and provide its unique socio cultural identity and also to meet the challenges of the times, so that all students irrespective of caste; creed, sex, and religion have access to education of a good quality. The policy emphasized the need for more financial assistance to education sector. ${ }^{4}$ India launched a series of national initiatives under the umbrella of NPE 1986/92 to enhance education. Many initiatives were taken under the umbrella of this policy i.e. National Literacy Mission (1988); Minimum Levels of Learning (MLL)Programme (1991); Programme of Action (POA) (1992); National Advisory Committee (1992); Districtspecific programmes (1993); District Institute of education and Training (DIETs) were structured as per the needs of district and effectiveness of institutions; State Councils for Educational Research and Training (SCERTs) were strengthened for purpose of recruitment of appropriate faculty, linking of DIETs, resource centres, maintenance of school buildings etc.

Programme of Sarva ShikshaAbhiyan (SSA) ${ }^{5}$ Sarve Shiksha Abhiyan (SSA) is a nation wide, time- frame programme, for quality and basic universal primary education in India with the effective partnership between

\footnotetext{
${ }^{3}$ National Policy on Education, (NPE), (1886) Ministry of Education, Government of India, New Delh.

${ }^{4}$ Ibid.

${ }^{5}$ Available at www.ssa.nic.in/, Accessed on 7, March 2013
} 
Central, State and Local governments by involving the Panchyaty Raj institutions, the School Management Commettees, Village Education Commettees, Parents' Teachers Associations to reach its objectives i.e to provide useful and relevant elementary education for all children from 6 to 14 years by 2000. Its overall goals included universal access and retention, bridging of gender and social category gaps in education and enhancement of learning levels of children.
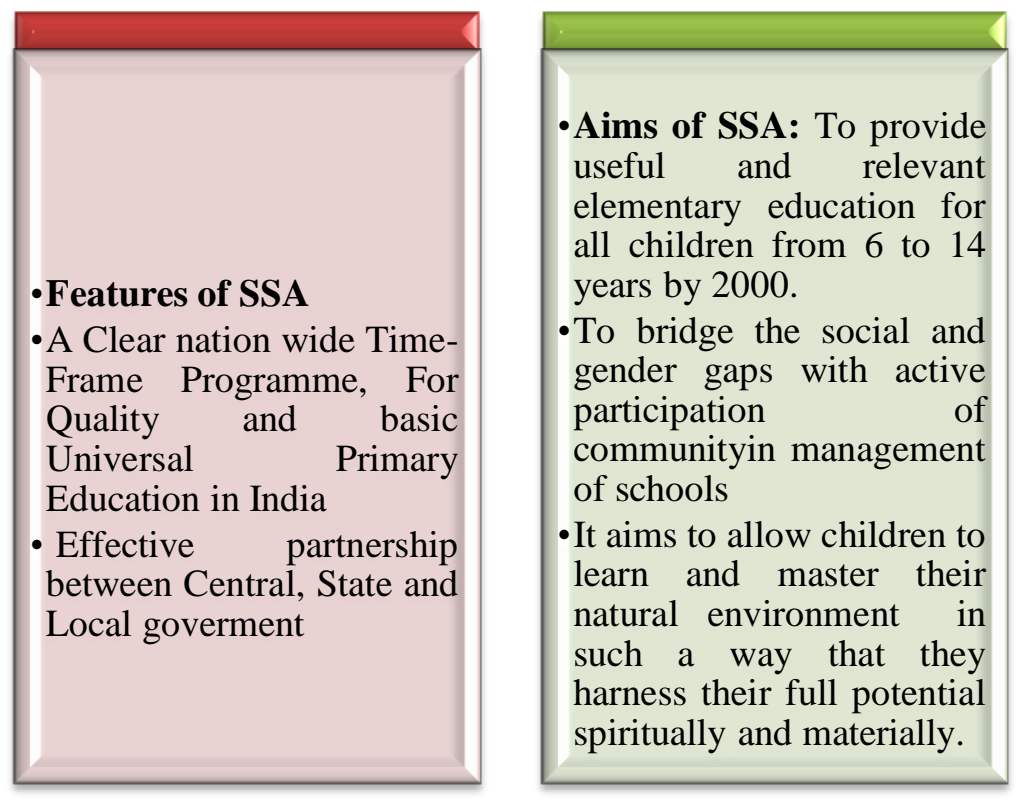

- Objecives of SSA
- Universal Enrolment: i.e.
All Children in School by
2003
- Complition of Universal
Retention of children in
school till they complet 5
years of schooling by
2010 and eight years of
elementary education by
2010 quality
- Satisfactory
elementary Education
- Bridging all gender and
social catgory gaps at
primary level

It aims to bridge the social and gender gaps with active participation of community in management of schools. It implemented institutional reforms as part of the SSA. It requirs the central and the state Governments to undertake:s

\section{Initiatives under Education for All (EFA) Campaign:-}

The World Education Forum, held in Dakar (2000), reiterated the commitment of the global community and approved a comprehensive set of goals in the areas of early childhood care in education, primary education, gender, youth and adolescent, adult education and quality of education. Following this commitment, India prepared a National Plan of Education (2002) delineating various programmes and strategies for achieving various Education for All (EFA) Goals. Subsequently, the mid- term assessment of progress of EFA goals, undertaken in 2005, underscored the concern for equity and inclusion and highlighted the need for accelerating the efforts for achieving EFA goals.

The Right of Children to Free and Compulsory Education Act (RTE), 2010:-

Providing free and compulsory education to all children is a goal that is enshrined in the Indian Constitution as a Fundamental Right. This, indeed, is also the focus of the World Declaration on 'Education for All', adopted as an international campaign.

The RTE Act provides legal entitlement to free and compulsory education to all children in the age group of six to fourteen years is a fundamental right under article $21 \mathrm{~A}$, inserted in the constitution (i.e. $86^{\text {th }}$ Amendment, 2002), This act mandated norms, standards, free entitlements, provided a justifiable legal framework that entitles all children between the ages of 6-14 years for free of cost and compulsory admission, attendance and completion of elementary education in India.

It provides for development of curriculum in consonance with the values enshrined in the Constitution, and which would ensure the all-round development of the child, building on the child's knowledge, potentiality and talent and making the child free of fear, trauma and anxiety through a system of child friendly and child centred learning" 6

It provides for appointment of appropriately trained teachers, i.e. teachers with the requisite entry and academic qualifications. It also negates the physical punishment and mental harassment, it also enacted 6 month imprisonment

${ }^{6}$ http://mhrd.gov.in/rte Accessed on 4, January 2015 
to teacher if pupil is abused, punished physically or harassed mentally. It also fixed the academic responsibilities of teachers and made provisions for development of school curriculum. It standardizes the school working hours and school teacher working days. It standardized the norm regarding Classroom Teacher Ratio and Pupil Teacher Ratio in schools.

\section{Realignment of programmes:-}

Steps have been initiated to harmonize the vision, strategy and norms under Sarva Shiksha Abhiyan (SSA) with RTE norms which lead to their realignment with each other. ${ }^{7}$ It provides for children's right to education that is free from fear, stress and anxiety by removing corporal punishment, improving school infrastructure. Other steps were taken under SSA was to reduce private cost of education by incentive scheme linked to attendance for SCs/STs, girls, and other poor children. ${ }^{8}$ Many steps by government for the improvement of the delivery system of elementary education under SSA are, Community ownership, Institutional Capacity Building by improving the role of major agencies i.e. NIEOA, NCERT, SCERT etc.

Capacity Building: Strengthening institutional and human capacities for effective planning and management of educational programmes. To strengthen the institutions and various institutions and educational agencies at national, state, district and block levels such as State Councils of Educational Research and Training (SCERTs), District Institutions of Education and Training (DIETs), Block Resource Centres etc to train teachers academically and professionally and to build in capacities and skills of other educational functionaries.

Community participation in planning and implementation of EFA programmes has been institutionalised through enactment of $73^{\text {rd }}$ and $74^{\text {th }}$ Amendments. Local Self governments have been authorised for "social audit" of local school education. Village Education Committees has been set with well established formal structured mechanism, which involves communities and people on local issues related to education. Parent Teacher Associations (PTAs), School Management Committees (SMCs), District Literacy Committees (DLC) has also established for monitoring the education institutions, play significant role in quality education. In the local campaign of EFA, NGOs and civil societies also play a key strategy role for accelerating its progress towards its goal achievement.

\section{Primary Education in India: Major Findings and Remonstrance:-}

As the EFA agenda approaches the 2015 deadline, as it's a great pleasure that India not only tracks the progress made towards the EFA goals but also highlights different progress rate in different parts of the nation. India, undoubtedly, has made substantial progress towards achieving EFA goals during the last two decades. The efforts put in by the Indian Government, various agencies, academicians etc for undertaking the EFA goals and above all to all the State Governments and Union Territory Administrators in country whose educators, teachers and academician and communities have all contributed unstintingly to this massive national endeavor of reaching the EFA goals in the country. There is brief review of the progress made in with respect to each of the EFA goals and the challenges that remain to be addressed.

* Growth of School Education: As per the Annual Report of "Education for All" 2014-15 India has witnessed phenomenal growth of school education, not only in terms of institution, infrastructure, but also in excess, enrolment and retention rate also. There is significant reduction in gender disparities at national, state and at the local level in India 9 .

* Growth in Primary Schools: Over a period of time, a steady growth in schools has seen in the recent years as $1,98,493$ new school has opened from 2002-03 till 2013-14 in India which is 24.41 percent of total primary schools of the nation. More than 95 percent schools have a building. 96 percent the total new school opened in rural areas. ${ }^{10}$ There are several categories of schools in India. There is significant growth of educational institution in India. During the period 2000-01 to 2013-14, the total number of primary schools (schools with only primary section) has increased by 34.5 percent i.e. from $6,38,738$ to $8,58,916$ schools). ${ }^{11}$ As it may be perused from the Chart 1

\footnotetext{
${ }^{7}$ Report to the People on Education, (2011-12), New Delhi; Ministry of Human Resource and Development (MHRD) Government of India, pp. 14-3.1

${ }^{8}$ Available at www.mhrd.gov.in/elementaryeducation1, Accessed on 13 March 2014.

${ }^{9}$ Education for All: Towards Quality with Equity (2014-15) NEUPA, MHRD, New Delhi

${ }^{10}$ Ibid.

11 Ibid.
} 


\section{Chart 1: Growth in number of Primary Schools in India (Schools with only primary Section)}

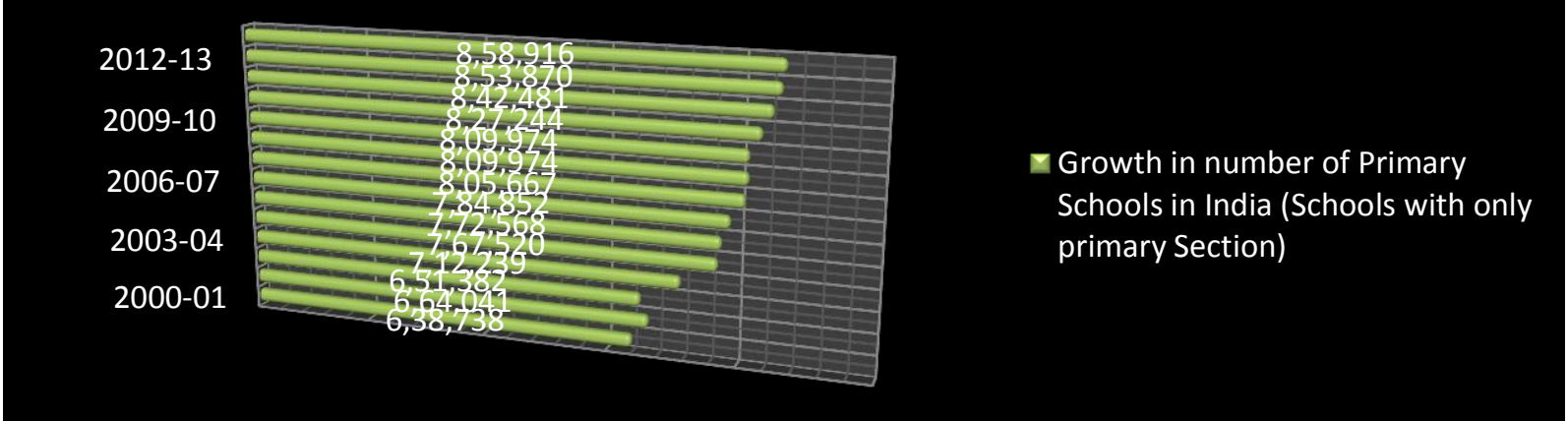

Source: Statistics of School Education, 2007-08, MHRD, Goi and Unified System of Education U-DISE), National University of Educational Planning and Administration (NEUPA)

* Access to school, has improved for most of the children as almost all areas have schooling facility within close vicinity of $3 \mathrm{~km}$ with the different form of schooling (such as community schools, mobile schools, distance learning and through contracting out their responsibilities to various types of Non Government organisations etc.

* Enrolment: according to the recent data (NUEPA, 2013), As many as 14.1 lakh elementary schools enrol of 137.1 million learners at the primary level and 64 million at the upper primary level. ${ }^{12}$

* Retention: According to Annual report of EFA 2014-15, India's One of the world's largest Mid Day Meal program provides 108 million children school meals daily to help retention.

* Basic Facilities in Schools: As per Annual report of EFA 2014-15, there is improvement of basic facilities in schools. In India school and other indicators, facilities in schools have improved significantly it may be physical, ancillary or teaching- learning facilities. Some of the other major facilities available in schools are:

* Drinking Water Facility: About 94.87 percent schools in 2013-14 had drinking water compared to 94.87 percent in 2012-13 and 83 percent in 2005-06. ${ }^{13}$

* Toilet Facility: The percentage of schools with boys' toilet is 94.45 out of which 92.67 percentage are functional compared to 84.63 percentage of schools have girls' toilet out of which 91.62 are functional. Around 45 percentage schools have hand wash facility available near toilet. ${ }^{14}$

* Computer Facility in Schools: During the period 2004-05 to 2013-14, the number of schools with computers increased substantially from 8.99 to 23.30 in India. ${ }^{15}$

* Mid-Day Meal Scheme: Providing nutritious food to all children under the mid-day meal scheme is one of the ambitious programmes of the government. In 2006-07, 29 percent of schools managed by the government (including aided schools) had kitchen-shed in school. ${ }^{16}$

* Financial Assistance to Schools: Over a period of time, the number of schools receiving school development and TLM grants increased substantially. Compared to 7,24,682 schools that received school development grant in 2003-04, the corresponding figure in 2007-08 was 8,82,745 schools (79.67 percent), reaching a high of $10,11,788$ (69.84) in 2012-13.

\footnotetext{
${ }^{12}$ NUEPA, 2013. Elementary Education in India: Progress Towards UEE, Flash Statistics, DISE, 2011-12, Provisional; NUEPA, New Delhi, India.

${ }^{13}$ Education for All: Towards Quality with Equity, (2014-15) National Educational University of Planning and Administration (NEUPA), New Delhi

${ }^{14}$ Ibid.

${ }^{15}$ Ibid.

${ }^{16}$ Ibid.
} 
Enrolment-Based Indicators in Primary Education in India:-

Enrollment in Primary Schools:-

The enrolment in primary classes increased between 2000-01 to 2013-14. Enrolment in primary education increased steadily up to 2010-11 and then showed a declining trend, as it is concluded from the chart 1 . The enrolment in primary education reached the highest level in 2011-12 (137.1 million) and then declined to 134.8 million in 201213 and to 132.4 million in 2013-14. Between 2011-12 and 2013-14, the total enrolment in primary education decreased by 4.7 million, while the enrolment of girls and boys decreased by 2.5 million and 2.2 million respectively.

Chart 1:- Showing Enrollment in Primary Education in India:

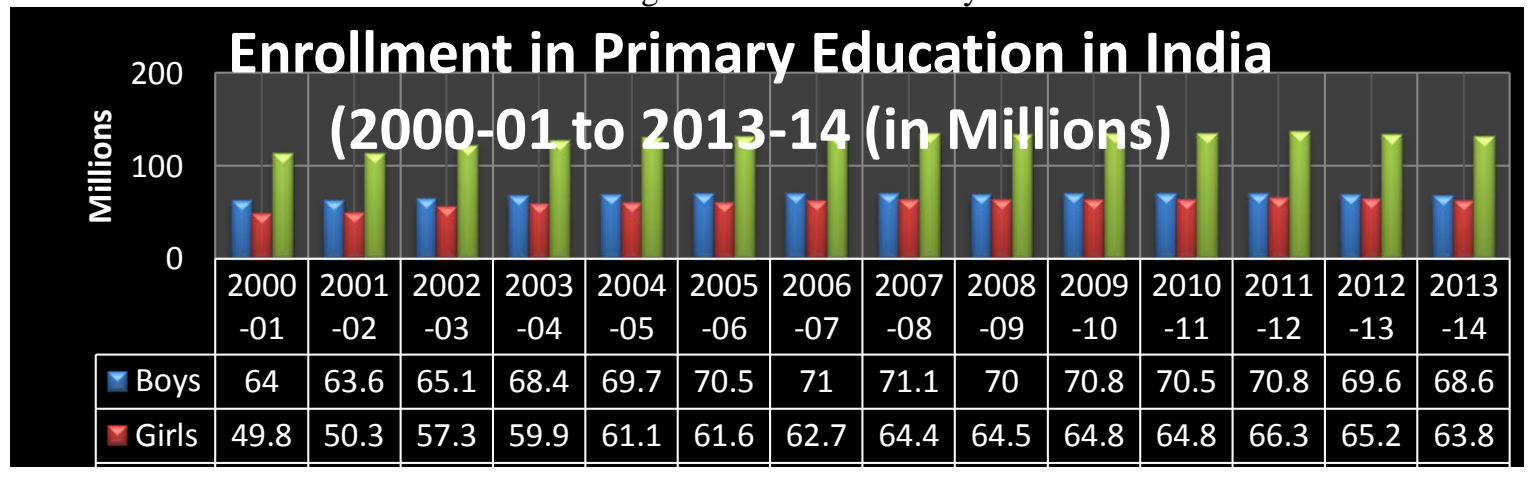

Source: Statistics of School Education, 2007-08, MHRD, Goi and Unified System of Education U-DISE), National University of Educational Planning and Administration (NEUPA)

Gross Enrolment Ratios (GER):-

The gross enrolment in primary classes increased from 95.3 million in 2002-03 to 116 million in 2010-11 and 108 million in 2011-12 and there after it is showing a decreasing trend. It decreased to 106 million in 2012-13 and to 101.4 in 2013-14. As it may be perused from the chart 1 .

\section{Gross Enrollment Ratio in Primary Education (2000-01 to 2013-14)}

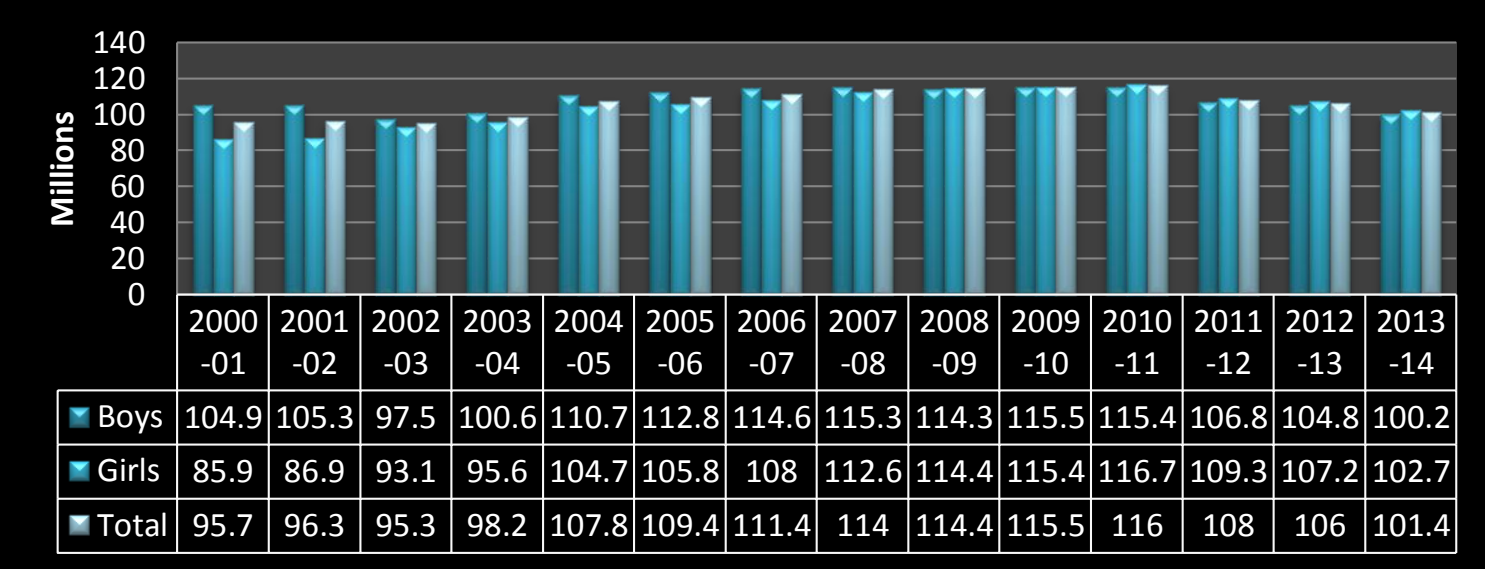

Source: Statistics of School Education, 2007-08, MHRD, Goi and Unified System of Education U-DISE), National University of Educational Planning and Administration (NEUPA)

Improvement in Pupil Teacher Ratio:-

Increase in the number of teachers is also reflected in the pupil-teacher ratio which has shown consistent improvement. Overall PTR was hovering around 30, it has reduced significantly from 36 in 2005-06. During 201314 , at the primary level, it was 25 students per teacher. Number of districts where PTR was above 30 was $219 .{ }^{17}$

\footnotetext{
${ }^{17}$ Id: at 23
} 


\section{High Transition Rate from Primary Level to Upper Primary Level:-}

One of the other important indicators that are essential to achieve UEE is a high transition from primary level to upper primary level of education. As per the EFA report of 2014-15 High Transition Rate from Primary Level to Upper Primary Level has improved significantly from 64.48 percent in 2002-03 to 89.58 percent in 2012-13 but declined slightly to 81.13 percent in 2006-07. Both Boys and Girls have a transition rate of about 89 and 90 percent respectively.67.68 and 78.06 percentages respectively. ${ }^{18}$

\section{Ratio of Girls to Boys:-}

The average of 662 districts in 2013-14 indicates a ratio of girls to boys enrolment of 0.93 which was 0.94 in 201213 in primary classes. ${ }^{19}$

Table 1:- Drop-Out Rates Parentage In Primary Education (All Categories of students) (class $1^{\text {st }}$ to $\left.5^{\text {th }}\right)(2000-01$ to 2008-09)

\begin{tabular}{|c|c|c|c|}
\hline Years & Boys & Girls & Total \\
\hline $2000-01$ & 39.7 & 41.9 & 41.7 \\
\hline $2001-02$ & 39.4 & 39.9 & 39 \\
\hline $2002-03$ & 35.9 & 33.7 & 34.9 \\
\hline $2003-04$ & 33.7 & 28.6 & 35.5 \\
\hline $2004-05$ & 31.8 & 25.4 & 29 \\
\hline $2005-06$ & 28.7 & 21.8 & 25.6 \\
\hline $2006-07$ & 24.6 & 25.7 & 25.1 \\
\hline $2007-08$ & 25.7 & 24.4 & 24.9 \\
\hline $2008-09$ & 26.7 & 22.9 & \\
\hline \multicolumn{2}{|c|}{ GOI. } \\
\hline
\end{tabular}

Most of the drop out students, girls are more as compare to boys. Dropout Rates Percentage in primary education is shown in Table 1. Percentage girls' enrolment shows a decrease from 2012-13 to 2013-14. At primary level it decreased from 48.36 (2012-13) to 48.20 in $2013-14$ which was 48.22 percent in $2007-08^{20}$. No doubt there is enhancement in Retention Rate in primary education. One of the essential requirements to achieve UEE is to retain students in the education system. A few states have almost achieved the goal of universal retention at primary level.

\section{Conclusion:-}

In spite of several efforts made by the government, the target of Universalisation of Elementary Education (UEE) has not been achieved even after more than six decades of independence. The some basic reasons for the present low education rate in the state is low allocation of resources, poor deployment of teachers and high dropout rate and poor teaching quality. ${ }^{21}$

\section{Quality Education:-}

No doubt there is growth in education quantitatively but when comes to the quality education. Which is sometime far away from ground reality, as reported by Pratham, There is not much quality education in India specially in rural schools. Students are lacking in Arithmetic and language skills.

\section{Lag between legislation and ground Reality:}

India has put in place comprehensive capacity development programmes. Most discussion in this area is of 'gaps' in the capacity to plan and formulate policy, linked to the 'gap' in good quality data and monitoring and evaluation systems. Of equal importance, however, is the constraint resulting from inadequately designed bureaucratic systems, organizations and institutions that can restrict the effective implementation of activities ${ }^{22}$

\footnotetext{
18 Ibid.

${ }^{19}$ Id: at 48

${ }^{20} \mathrm{Id}$ : at 45.

${ }^{21}$ PullaRao, (1998) Economics of Primary Education, Jaipur; Rawat Documentatons,

22 Op.cit, Thematic Paper on MDG 2 UNDG,
} 


\section{Scarcity of Trained Teachers:-}

There is less availability of trained teachers in India. Teachers are not trained, else they are untrained or semi trained.

Financial Scarcities:-

Finance is often pinpointed as most important hurdle. No doubt India has increased its financial inputs in the education sector but still financiers are not sufficient.

\section{Conclusion:-}

Administrative gaps, financial hurdles, quality less education, and other many policy or program lags can be easily taken over by improving governance in India. It is vital for the achievement of MDG 2 at national level in India. Bad governance shows characteristics of loose administrative accountability, unresponsiveness towards demands and need of people and society corruption etc. They act as big hurdles in achievement of primary education goals. Strong political will and administrative accountability can do wonders in upliftment and achievement of desired level of education in India. It may be the scarcity of finances or poor deployment of teacher, teacher training or training untrained or semi trained teacher, (who may be already in service) or may be quality education. Everything lies directly or indirectly in political will and administration dedication. Better monitoring system, transparency, accountability, responsiveness towards educational needs could be very straight away solution to the problems associated to primary education. There is a need to increase financing to reduce financial gaps and to improve the quality of service provision through better policies and stronger institutions. Targeted investment of adequate resources with disaggregated actions are necessary to reduce regional and inter-state disparities and simultaneously focusing on a results-based approach to education in order to pursue primary education goal of "learning for all" in a post-2015 India. 